Available online at website :

http://e-journal.adpgmiindonesia.com/index.php/jmie

JMIE: Journal of Madrasah Ibtidaiyah Education, 4(1), 2020, 100-113

\title{
MODEL PEMBELAJARAN TEMATIK INTEGRATIF BERBASIS KURIKULUM 2013 DI MADRASAH IBTIDAIYAH
}

\author{
Jefryadi \\ Institut Agama Islam (IAI) Al-Azhaar Lubuklinggau \\ Email: jefryadihudiono@gmail.com
}

Naskah diterima : 15 Maret 2020, direvisi : 29 April 2020, disetujui : 30 April 2020

\begin{abstract}
The 2013 curriculum-based integrative thematic learning model is a learning strategy that involves several subjects into a learning theme that uses an interdisciplinary approach to provide meaningful experiences to students in the learning process. The application of this learning model requires adequate infrastructure and mature teacher understanding concepts. Integration and success in this learning model can be seen from the aspect of understanding of the learning model, aspects of the learning strategy, and aspects of the use of media in learning. Because every teacher has their own characteristics in conveying learning to students, in order to achieve learning objectives. Therefore the writer wants to examine more deeply how the application of the 2013 curriculum-based integrative thematic learning model in MIN Yogyakarta II and MI Ma'had Islamy Kotagede Yogyakarta?. This research made to know how integrative thematic learning models, the strategies applied and the media used by teachers in the application of this study. This research is categorized in the type of field research (Field Research) which is descriptive with qualitative research methods using theories about integrative thematic learning models then proceed to drawing conclusions. The results showed that in general these two institutions had applied the integrative thematic learning model well. The teacher's mastery of the learning model and the methods used by the teacher in linking learning material are already good so that learning becomes a unified and meaningful whole for students. Then the strategies used by the teacher in planning learning activities, preliminary activities, core activities and closing activities are quite diverse and adjusted to the needs and interests of students. The media used have their respective characteristics and are always adapted to the learning material to be taught. Although they have differences in learning strategies and the media used in teaching, however, they have the same goal of achieving success in teaching so that the expected goals can be achieved and provide meaningful experiences to students.
\end{abstract}

Keywords: Integrative Thematic Model, Curriculum 2013

Pengutipan: . Jefryadi. (2020). Model Pembelajaran Tematik Integratif Berbasis Kurikulum 2013 di Madrasah Ibtidaiyah. JMIE: Journal of Madrasah Ibtidaiyah Education,4(1), 100-113. jmie.v4i1.174. 


\section{PENDAHULUAN}

Model pembelajaran diperlukan dalam setiap proses pembelajaran, Model pembelajaran ini yang dinilai cukup efektif yang bisa mengubah peserta didik menjadi lebih baik yaitu pembelajaran tematik. dalam kurikulum 2013 model pembelajaran tematik integrative ini sangat tepat diterapkan. Sebelum kurikulum 2013 muncul kurikulum yang diterapkan yaitu KTSP. Pembelajaran dalam kurikulum 2013 diharapkan bisa membangun karakter siswa dalam pendidikan. Karakteristik siswa akan berbeda sesuai dengan apa yang kita lihat dilapangan. Oleh sebab itu karakter siswa sangatlah penting dibangun dalam proses pembelajaran yang berlangsung.

Model pembelajaran (teaching models) merupakan suatu perencanaan dalam pelaksanaan pembelajaran dan evaluasi pembelajaran yang disusun guna untuk mencapai tujuan belajar (Syah, 2004:189). Model tematik integrative berpedoman pada pendekatan yang akan digunakan, beserta tujuan pengajaran tahapan dan semua hal yang digunakan dalam proses pembelajaran. Sehingga dapat menjadi suatu model pembelajaran terpadu yang akan di terapkan didalam proses pembelajaran.

Pembelajaran tematik terpadu merupakan suatu cara belajar dan penerapannya sangat luas dan bisa diterapkan disemua jenjang satuan pendidikan (Syah, 2004:6). Selain itu pembelajaran terpadu juga memiliki arti sebagai model belajar yang diterapkan dengan melihat minat serta bakat, dengan tidak hanya memperhatikan sisi kognitif akan tetapi juga melihat dari afektif dan psikomotorik peserta didik. Dengan harapan dapat menjadikan siswa akan bersemangat dalam belajar.

Adapun model pembelajaran ini diciptakan untuk penerapan pembelajaran berdasarkan sebuah tema yang ditentukan berdasarkan pendekatan antar bidang studi. Dimana akan dilihat dari pokok bahasan setiap materi yang bisa digabungkan kedalam sebuah tema. Pada hakikatnya pembelajaran ini merupakan pembelajaran yang menuntut siswa lebih aktif dan terfokus dalam semua subyek pembahasan (Student Center) dimana seorang guru hanya menjadi seorang fasilitator yang mengarahkan pembelajaran (Soleh, 2014:59).

Proses pembelajaran pada umumnya sudah tentu pasti memiliki sebuah masalah atau kesulitan. Pada kenyataannya didalam proses pembelajaran guru sering kali lebih aktif dari pada peserta didik, tidak aktifnya peserta didik tersebut dikarenakan model pembelajaran yang digunakan sangat pasif dan membuat siswa kurang bersemangat dalam belajar. Selain itu ada alternative lain yang bisa digunakan seorang guru untuk mengatasi hal tersebut. Guru dapat memilih pembelajaran terpadu sebagai cara untuk menjadikan siswa lebih antusias dan lebih aktif dalam proses pembelajaran. Berdasarkan uraian diatas pembelajaran tematik ini menjadi alternative yang sangat tepat yang dipilih untuk membuat siswa aktif dalam belajar.

Selain itu pembelajaran tematik ini tidak bisa lepas dari tema pembelajaran yang digunakan untuk mengaitkanya ke dalam beberapa bidang studi yang membuat suatu proses 
belajar menjadi menyenangkan ( Hajar, 2013:6). Makna pembelajaran ini yaitu suatu proses pembelajaran yang menggunakan tema. Berdasarkan penerapannya tema diambil kehidupan siswa yang diangggap menjadi pokok pembahasan. Penerapan model ini tidak terlepas dari peranan kurikulum, dimana dilihat dari kedalam dan keluasan analisis kurikulum yang diterapkan dalam pelaksanaan model ini. Pengelompokan pembelajaran terpadu salah satunya yaitu model tematik integratif (Trianto, 2014:147). Pada dasarnya pembelajaran ini yaitu pembelajaran yang diciptakan atau dicetus untuk ditentukan berdasarkan hak-hal yang dekat dengan kehidupan siswa sehingga pembelajaran ini akan bermakna.

Dalam pembelajaran ini juga menawarkan beberapa model yang bisa diterapkan bersamaan sehingga pembelajaran akan lebih berwarna dan bermakna, adapun salah satu model tersebut adalah model pembelajaran integratif. Model integratif adalah suatu model terpadu yang melihat sisi pendekatan antar bidang studi (Trianto, 2014:116). Model ini diterapkan dengan menemukan keterampilan peserta didik serta melih tumpang tindihnya suatu mata pelajaran yang kemudian bisa digabungkan menjadi lebih praktis dan efisien. Kegiatan awal yang dilakukan guru yaitu melihat konsep konsep keterampilan, sikap yang ada didalam setiap mata pelajaran lalu berusaha menelaah dan mempertimbangkan suatu keputusan yang akan dilakukan dalam menggabungkan setiap mata pelajaran berdasarkan silabus, rpp dan melihat dari manfaat dan tujuan pembelajaran.

Proses keterpaduan dalam penerapan model ini dapat dicermati dalam bagaimana pembejaran ini nantinya diterapkan oleh guru. Dalam pelaksanaanya akan menuntut siswa lebih aktif dari seorang guru yang menjadi sebagai pembimbing anak dalam proses pembelajaran. Strategi pembelajaran yang berkenaan dengan proses dalam penerapan pembejaran yang nyata dan keaktifan siswa dalam pembelajaran merupakan poin utama dalam penerapan pembelajaran ini. Bentuk pembelajaran tematik integratif ini merupakan bentuk pembelajaran yang menuntut siswa untuk lebih berusaha memberikan respon atau ikut serta aktif dalam pembelajaran karena tugas seorang guru dalam pembelajaran ini memberikan sebuah stimulus yang lalu di respon siswa melalui keaktifan yang dimunculkan dalam proses belajar dikelas.

Pembelajaran tematiik integratif memberikan tugas kepada guru sebagai pengajar yang harus memberikan suatu materi pembelajaran yang sesuai dengan pengalaman langsung (direct experiences) yang dialami peserta didik dalam kehidupanya. Adapun yang dimaksud dengan proses pembelajaran tematik integratif yaitu siswa langsung mempraktekkan kegiatan belajar secara langsung dengan binaan guru dikelas. Artinya, siswa-siswa melakukan kegiatan belajar yang nyata dan langsung mereka sendiri yang mendemontrasikan materi belajar.

Model tematik integratif ini mewujudkan pengalaman dalam proses belajar yang sesuai dengan kebutuhan siswa, lebih bermakna, mengembangkan keterampilan berfikir siswa serta menumbuhkan keterampilan dalam bekerjasama, serta bisa menerima pendapat orang lain. 
Setiap proses belajar tentu saja terdapat kelebihan dan kekurangan, kekurangan atau kelemahan dalam pembelajaran tematik integratif yaitu pembelajaran ini sulit diterapkan secara penuh selain itu juga pembelajaran ini tidak bisa diterapkan oleh guru yang belum memahami secara penuh mengenai konsep dari pembelajaran ini. Karena dalam penerapannya banyak sekali konsep yang berbeda dari pembelajaran biasa yang sering diterapkan sebelumnya. Karena pemahaman dalam penerapan pembelajaran ini dilakukan dari proses perencanaan, pelaksanaan dan evaluasi yang saling berhubungan.

Seorang guru dapat dikatakan berhasil dalam penyampaian materi pembelajaran tematik integratif ini yang memberikan sebuah materi pembelajaran yang dekat dengan kehidupan peserta didik otomatis menumbuhkan sebuah stimulus yang langsung bisa di respon oleh peserta didik melalui pemikiran dan pengamatan dalam proses pembelajaran yang sedang berlangsung.

Proses belajar pada umumnya memiliki kendala serta hambatan atau permasalah dalam penerapannya. Begitu pula yang terjadi dalam penerapan pembelajaran tematik integratif dalam kurikulum 2013. Biasanya masalah yang akan muncul adalah pada guru. Karena keberhasilan dalam proses pembelajaran itu tergantung pada guru yang mengajar. Bisa kita lihat dilapangan bahwa pelatihan pembelajaran tematik ini belum didapatkan oleh semua guru. Masih banyak sekali lembaga Pendidikan yang belum tersentuh dengan kegiatan ini. Kesulitan yang akan timbul adalah bagimana guru akan mengajar siswa di kelas 4 SD/MI. Karena pada kelas rendah siswa telah terbiasa dengan pembelajaran yang diterapkan sesuai dengan kuriukulum KTSP 2006 yang tidak menerapkan model pembelajaran tematik didalamnya. Hal ini menjadi sebuah perbedaan yang sangat mencolok yang akan diterima siswa. Selain itu guru juga akan kebingungan dalam menerapkan kurikulum baru karena menerapkan pembelajaran baru itu tidaklah mudah, diperlukan sebuah pemahaman konsep yang mendalam sehingga pembelajaran itu dapat berjalan sesuai dengan apa yang diinginkan.

Permasalahan selanjutnya adalah dalam kegiatan pembelajaran . Adapun kegiatan inti pembelajarn tematik dilakukan berdasarkan tahapannya. Kemudian pelaksanaan pembelajaran di SD/MI terbagi pada tema, sub tema dan kegiatan pembelajaran.. Hal akan menjadi permasalahan yaitu apa yang akan dilakukan guru dalam pelaksanaannya dan bagaimana lima tahapan pembelajaran tersebut bisa dilakukan oleh guru dalam penerapan pembelajaran ini.

Selain kedua masalah diatas selanjutnya yaitu berkenaan dengan sumber belajar. Buku siswa merupan suatu sumber belajaran yang sangat penting. Kemudian yang akan menjadi permaslahan adalah ketika buku siswa tidak dikembangkan oleh guru. Dalam pembelajaran ini setiap pembelajaran akan memiliki buku yang berbeda. Misalnya 6 pembelajaran, akan memiliki 6 buah buku berdasarkan tema yang akan dipelajari. Kemudian guru akan mengalami kesulitan bila sumber belajar tidak tersedia. Bagi sekolah yang berada di daerah perkotaan tentu bukan masalah, namun tidak demikian bagi SD/MI yang berada di pelosok desa. 
Alasan pemerintah mengganti kurikulum dari KTSP menjadi Kurikulum 2013 adalah untuk meningkatkan kualitas pendidikan nasional (Prastowo, 2014:40-43). Menurut Muhammad Nuh bahwa pada Kurikulum 2013 ini dapat memberikan sebuah jawaban mengenai tentang model belajar apakah yang sesuai untuk diterapkan sesuai dengan perkembangan zaman. Pada kurikulum 2013 memiliki pola pembelajaran berpusat pada siswa (Student Center). Pembelajaran ini diharapkan mampu membangun karakter peserta didik dalam proses pembelajaran dan menjadikan pembelajaran tersebut lebih bermakna dan menyenangkan.

Kurikulum 2013 menawarkan pembelajaran yang mengedepankan pengalaman langsung (direct experience). Peserta didik dapat merasakan sistem pembelajaran yang berbeda dan menyenangkan sehingga pembelajaran tersebut menjadi bermakna dan menumbuhkan semangat dalam proses pembelajaran. Tetapi dalam penerapan kurikulum 2013 ini terdapat beberapa kesulitan yang dialami guru dalam proses pembelajaran, terutama dalam aspek administrasi penilaian. Penilaian yang dilakukan dalam kurikulum ini yaitu selain dari sisi kognitif juga melihat dari aspek psikomotorik dan afektif.

Di pilihnya kedua lembaga tersebut karena berdasarkan observasi yang dilakukan pada kegiatan pra penelitian, bahwa lembaga ini memiliki persamaan dan perbedaaan baik dalam segi kegiatan pembelajaran, kompetensi guru dan keunikan dalam proses pembelajaran. Kualifikasi guru di kedua lembaga ini sebagian besar berijazah S-1 dan berlatarkan pendidikan. Selain itu guru-guru di kedua lembaga ini juga aktif mengadakan kegiatan seperti pelatihan, penataran, seminar, wawancara, dan workshop. Dalam kegiatan pembelajaran keduanya memiliki semangat mengembangkan pembelajaran yang berpusat pada peserta didik.

Di samping memiliki persamaan kedua lembaga ini juga memiliki perbedaan. Secara kelembagaan di MIN 2 Yogyakarta memiliki banyak peserta didik yang menempuh pendidikan di lembaga ini. Dan juga jumlah peserta didiknya terbagi menjadi dua rumpun kelas pada masing-masing tingkatan. Penerapan kurikulum 2013 diterapkan pada setiap kelas dari kelas 1 hingga kelas 6. Pada proses pelaksanaan pembelajaran melakukan tahapan pembelajaran berdasarkan RPP. Pada proses pembelajaran ini guru selalu menyesuaikan dengan petunjuk yang ada di buku siswa. Akan tetapi hambatan dirasakan pada bidang sarana dan prasarana. Karena dalam segi teknologi lembaga ini telah memiliki sarana prasarana yang lengkap akan tetapi dalam segi autentik atau sarana prasarana yang langsung terjun kelapangan itu masih kurang.

Pembelajaran yang berlangsung menyenangkan dan memiliki kekhasan tersendiri, karena banyak praktik-praktik pembelajaran yang dilakukan sehingga membuat pembelajaran tersebut tidak monoton. Akan tetapi semua itu hanya dilakukan didalam kelas. Dalam proses pembelajaran guru juga mengalami kesulitan dalam mata pelajaran Bahasa Indonesia, PKN, dan IPS karena pembelajaran itu sering memiliki KD yang hampir sama dan juga banyak 
materi yang tidak tuntas dalam proses pembelajaran. Dalam segi penilaian memiliki banyak aspek yang dinilai bukan hanya aspek kognitif tetapi juga aspek psikomotorik dan afektif sehingga membutuhkan kecermatan dan waktu yang lama bagi guru untuk melakukan penilaian dalam pembelajaran. tetapi banyak materi yang tidak tuntas.

Pada MI Ma’had Al Islamy lembaga ini menggunakan kurikulum 2013 yaitu kelas 1 dan kelas 4. Jumlah peserta didik di lembaga ini hanya rata-rata 15 sampai 13 siswa pada setiap kelas. MI Ma’had Al Islamy Yogyakarta ini disebut juga dengan MI “bengkeel” Karena banyak peserta didik yang tidak naik kelas atau terdapat masalah disekolah sebelumnya dan kemudian masuk ke lembaga ini. MI Ma’had Al Islamy Yogyakarta selalu menerima peserta didik yang ingin menempuh pendidikan di lembaga ini karena lembaga swasta ini memiliki tujuan untuk membantu memperbaiki dan menumbuhkan semangat peserta didik untuk selalu menempuh pendidikan yang berlandaskan agama Islam. Proses pembelajaran tematik integratif di lembaga ini berjalan dengan lancar dan menyenangkan. Berdasarkan hasil wawancara yang dilakukan dengan salah satu guru tematik dilembaga sekolah ini bervariasi dan menyenangkan. Dikarenakan kegiatan yang diterapkan sangat bervariasi dalam proses pembelajaran. Kemudian proses belajar yang dilakukan guru tidak hanya mengajarkan materi di dalam kelas tetapi juga sering membawa peserta didik belajar diluar kelas seperti dihalaman kelas dan lingkungan sekitar sekolah. Akan tetapi guru mengalami sedikit kendala dalam pembelajaran matematika, karena dalam pembelajaran matematika ini materi yang dibahas sangat sedikit sehingga pemahaman konsep pada pembelajaran tersebut sangat terbatas.

Sarana dan prasarana dilembaga ini sudah cukup lengkap, tetapi guru lebih senang menampilkan sesuatu yang abstrak dalam pembelajaran seperti dalam materi pembelajaran tumbuhan guru langsung membawa peserta didik keluar kelas untuk memperhatikan tumbuhan yang ada disekitar, sehingga pembelajaran tersebut sangat menyenangkan. Akan tetapi dilihat dari aspek kognitif siswa berdasarkan hasil ujian mid semester menurun, karena materi yang diterima peserta didik kurang mendalam. Hal ini berbanding terbalik dengan aspek penilaian psikomotorik dan afektifnya. Karena siswa akan lebih terampil dan aktif dalam kelas. kemudian juga membentuk sikap yang lebih baik dari sebelumnya, dimana mereka lebih memaknai arti dari kebersamaan, kekompakan dan perduli terhadap sesama. Dalam aspek penilaian guru dalam lembaga ini sangat kesulitan, karena banyak sekali aspek penilaian yang sangat berbeda dengan kurikulum sebelumnya.

Berdasarkan latar belakang diatas, maka penulis berupaya untuk mengkaji lebih dalam terhadap permasalahan tersebut dan dituangkan dalam sebuah penelitian. Penelitian ini memfokuskan pada aspek penerapan model pembelajaran tematik integratif berbasis kurikulum 2013 studi kasus di MIN Yogyakarta II dan MI Ma'had Islamy Kotagede Yogyakarta . 
Jefryadi

\section{METODE PENELITIAN}

Penelitian ini dikategorikan pada jenis penelitian lapangan (Field Research) yang bersifat deskriftif, yaitu penelitian yang tidak dimaksudkan untuk menguji hipotesis tertentu, dengan melihat suatu keadaan atau gejala yang dilaksanakan di tempat atau lokasi di lapangan (Prastowo, 2011:186). Adapun metode penelitian yang digunakan yaitu metode penelitian kualitatif yang dilakukan secara natural sesuai dengan keadaan yang sebenarnya dilapangan (Arifin, 2011:140). Dipilihnya pendekatan pedagogik karena manusia adalah mahluk pedagogik yaitu mahluk Allah yang dilahirkan membawa potensi dapat dididik dan mendidik sehingga mampu menjadi khalifah dimuka bumi, pendukung dan pengemban kebudayaan yang dilengkapi dengan fitra Allah berupa bentuk atau wadah yang dpat diisi dengan berbagai kecakapan dan keterampilan yang dapat berkembang (Darajat, 2008:16). Sumber data penelitian ini adalah Guru dan Peserta didik di MIN 2 Yogyakarta dan MI Ma'had Al Islam Yogyakarta. Selain sumber data berupa manusia, peneliti juga mengambil data dari arsip sekolah, dokumentasi. Metode pengumpulan data dalam penelitian ini adalah metode yang dipakai untuk memperoleh informasi dari sumber guna untuk memperoleh data yang lengkap,tepat, dan valid. Beberapa macam metodenya yaitu : wawancara, observasi dan dokumentasi. Penelitian ini peneliti akan menggunakan trianggulasi untuk menunjukkan keabsahan data yang dikumpulkan. Trianggulasi merupakan proses penguatan berdasarkan catatan lapangan yang bisa dibuktikan dengan menggunakan data yang telah dikumpulkan (Emzir, 2010:82).

\section{HASIL DAN PEMBAHASAN}

Hasil penelitian ini menyajikan tiga poin utama, yaitu: pertama, Pemahaman guru terhadap model pembelajaran tematik integratif berbasis Kurtilas. Kedua, Strategi penerapan pembelajaran tematik integratif berbasis Kurtilas. Ketiga, Media pembelajaran yang digunakan guru dalam pembelajaran tematik integratif berbasis Kurtilas.

\section{Pemahaman Guru Terhadap Model Pembelajaran Tematik Integratif Berbasis Kurikulum 2013.}

Pemahaman guru terhadap model pembelajaran tematik integratif sudah sangat baik, dimana keduanya sudah memahami seluruh konsep tentang model pembelajaran tema integratif yang diterapkannya selama proses pembelajaran. Proses pembelajaran yang diterapkan dari kedua lembaga ini telah bisa dikatakan berhasil karena kegiatan yang diterapkan berupa suatu kegiatan pembeljajaran yang berpusat pada siswa/ peserta didik. dan memberikan proses belajar yang bermakna dari tema-tema yang diberikan dalam proses pembelajaran yang telah direncanakan yang sesuai keadaan siswa berupa kemampuan, minat, bakat, potensi dan kemampuan yang dimiliki siswa. Dalam penerapannya proses penerapan 
model tematik integratif di kedua madrasah ibtidaiyah ini, guru sangat mengusai materi yang diajarkan dan guru sangat mudah dalam mengaitkan beberapa mata pelajaran dengan pendekatan bidang studi yang dikaitkan kedalam satu buah tema pembelajaran. Trianto, (2010:43) berpendapat bahwa pembelajaran yang menggunakan pendekatan mata pelajaran. Sehingga pembelajaran ini menjadi sebuah pembelajaran yang efektif dan menyenangkan bagi peserta didik.

Sebagai contoh dalam kegiatan awal pembelajaran guru bertanya "apa materi pembelajaran yang akan kita pelajarai sekarang?" dan siswa menjawab "Hewan Langka Buk...." lalu ada seorang siswa bertanya kepada guru, "Buk, Burung Kakak Tua itu langka atau tidak bu?” dan Guru menjawab, "Iya burung Kakak Tua itu termasuk hewan yang langka". Lalu guru meminta siswa berdiri dan menanyakan kepada siswa "ada yang masih hafal lagu Burung Kakak Tua?" dan siswa menjawab, "hafal bu, lalu guru meminta semua siswa menyanyikan lagu Burung Kakak Tua bersama-sama sambil bertepuk tangan. Selain itu dalam materi yang sama guru menjelaskan tentang hewan langka kepada siswa lalu gurumeminta siswa supaya memperhatikan buku pelajaran, siswa diminta memperhatikan dan menyimak, guru membaca dengan lantang tentang tabel pembelajaran yang ada dibuku tematik siswa. Guru berada dibelakang dan siswa mencermati gambar yang ada dibuku. Guru bertanya hewan apa yang tidurnya paling lama? Siswa menjawab ular piton yaitu 18 jam. Dan bertanya hewan yang tidur paling sedikt yaitu jerapah 6 jam. Lalu guru bertanya berapa selisih waktu tidur dari kedua binatang tersebut. Guru meminta dua orang siswa menghitung persentasi didepan papan tulis. Guru dalam pembelajaran tematik integratif ini sangat dituntut untuk kreatif dan leluasa dalam mengajar. Seperti contoh pada hasil observasi diatas dalam kegiatan pembelajaran yang dilakukan oleh Ibu Wardani, untuk menumbuhkan semangat peserta didik dalm pembelajaran terlebih dahulu guru mengaitkan pembelajaran IPA dengan pembelajaran SBDP dengan menyanyikan lagu Burung Kakak Tua dengan suara yang lantang. Kemudian mengaitkan pembelajaran Bahasa Indonesia dengan Matematika. Banyak sekali cara-cara yang bisa digunakan guru dalam mengaitkan sebuah materi pembelajaran sehingga pembelajaran tersebut menjadi satu kesatuan yang utuh serta memberikan suatu makna paada siswa dalam proses penerapan model ini.

Kegiatan belajar yang diterapkan berupa sebuah kegiatan yang menuntut siswa lebih aktif dan memberikan gambaran proses belajar yang bermakna dari tema-tema yang diberikan dalam proses pembelajaran yang telah direncanakan sesuai dengan apa yang dibutuhkan peserta didik baik bakat minat, kemampuan serta kebutuhan siswa. Sanjaya (2006:99) menjelaskan bahwa kesuksesan pengaplikasian model ini dilihat dari kebutuhan peserta didik. Karena fungsi dari pendidikan adalah membentuk manusia agar memiliki karakter kreatif. Bukan hanya pendidik yang harus kreatif akan tetapi peserta didik juga memiliki karakter kreatif dalam penerapan pembelajaran tematik integratif berbasis kurikulum 2013. 
Jefryadi

\section{Strategi Penerapan Pembelajaran Tematik Integratif Berbasis Kurikulum 2013}

Strategi pembelajaran yang diterapkan oleh guru pada dua lembaga ini tidak jauh berbeda, karena masing-masing guru memiliki ciri khas tertentu dalam mengajar. Namun semua strategi tersebut memiliki tujuan yang sama yaitu untuk mencapai kesuksesan dalam mengajar sehingga tujuan pembelajaran dapat tercapai. Kedua lembaga tersebut dalam proses pembelajaran melaksanakan kegiatan pendahuluan, kegiatan inti dan kegiatan penutup menggunakan pendekatan saintifik. Dimana aspek pembelajaran saintifik seperti kegiatan mengamati, menanya, menalar, mencoba dan mengasosiasikan terlaksana dengan baik dalam proses pembelajaran sehingga para peserta didik memiliki jiwa atau karakter kreatif dalam mengolah hasil pembelajaran dan lebih banyak menelaah sendiri pembelajaran yang diberikan oleh guru. Aunillah (2011:87) menjelaskan bahwa fungsi dari pendidikan adalah membentuk manusia agar memiliki karakter kreatif.

Pertama, dalam proses pembelajaran kedua guru dalam lembaga ini telah mampu menciptakan kelas yang menarik dan sikap yang baik. Karena proses pembelajaran ditentukan dari bagaimana sikap guru ketika mengajar dikelas. Kemapuan untuk membuat suasana kelas menjadi nyaman merupakan tugas pokok dari seorang guru. Kebersihan serta penataan ruang kelas juga menjadi poin penting dalam kelangsungan kegiatan pembelajaran. Suasana menyenangkan yang diciptakan oleh kedua lembaga ini menjadikan kegiatan pembelajaran menjadi menyenangkan dan tanpa adanya tekanan sehingga peserta didik sangat senang untuk belajar dikelas.

Kedua, Kemudian kedua guru dalam lembaga ini memeriksa kehadiran siswa (presence, attendance). Hal ini sangat penting dilakukan. Seperti yang telah diterapkan kedua lembaga ini dalam mengabsen siswa. Pada kegiatan ini guru bisa menambahkan sisi perhatian yang lebih kepada siswa dangan menanyakan keadaan mereka dan memberikan motivasi sebelum kegiatan inti dilaksanakan atau bisa juga dengan memberiukan kuis tentang pembelajaran yang telah diberikan sebelumnya seperti yang telah diterapkan kedua lembaga ini.

Ketiga, Menumbuhkan kesiapan belajar siswa (readiness). Hal ini perlu diperhatikan dalam penerapan sebuah pembelajaran. Karena kesiapan belajar sangat menentukan sampai mana berhasilnya pembelajaran yang akan diterapkan. Dalam menciptakan kesiapan belajar siswa, yang dilakukan kedua lembaga ini khususnya yang dilakukan pada awal pembelajaran mempersiapkan semua fasilitas dan alat-alat pembelajaran sangat penting dilakukan dan memerlukan bimbingan dari guru. Terutama pada kelas rendah. Tetapi tidak menutup kemungkinan kelas tinggi juga memerlukan hal demikian guna untuk memperlancar proses belajar dan menjadikan siswa lebih memahami kegiatan tersebut.

Keempat, menciptakan suasana belajar yang demokratis maka diperlukan keterampilan guru dalam mengelola kelas. Guru harus menciptakan suasana belajar yang demokratis untuk membangun keberanian siswa dalam bertanya, menjawab pertanyaan yang di ajukan, 
berpendapat di depan kelas, unjuk kerja dalam tim / kelompok, dan sebagainya. Membuat siswa menjadi berani dalam berpendapat tidaklah mudah, maka peran guru sangat diperlukan dalam hal ini.

Kelima, membangkitkan motivasi belajar siswa, motivasi terbagi menjadi dua, yaitu motivasi intrinsic dan ekstrinsik. Dengan adanya motivasi ini, dapat menjadikan siswa lebih bersemangat dalam belajar, apalagi siswa telah menyadari bahwa apa yang dipelajari akan memberi manfaat dalam kehidupannya.

Keenam, membangkitkan perhatian siswa dalam proses pembelajaran. Guru dituntut harus dapat membangkitkan perhatian para siswanya supaya terfokus hanya pada materi yang sedang di paparkan oleh guru atau teman nya di depan kelas. Adapun kegunaan dari membangkitkan perhatian siswa di sela-sela atau selama proses pembelajaran ialah untuk memusatkan energi dan psikis anak dalam kegiatan belajar. Perhatian akan terpusat apabila ada kepentingan langsung dengan siswa dan punya karakteristik yang berbeda dengan yang lain. Oleh karena itu, dalam membangkitkan perhatian siswa, maka guru dapat memberikan beberapa penyegaran berupa lelucon atau permainan yang bervariasi untuk sekedar hiburan supaya siswa tidak merasa bosan terhadap proses pembelajaran yang sedang berlangsung dengan durasi 5 10 menit saja dan kemudian kembali ke pokok materi yang akan di pelajari pada pertemuan itu.

Ketujuh, membuat kaitan. Membuat kaitan dalam pembelajaran tematik Integratif sangatlah penting karena pada penerapan model ini tema menjadi bagian terpenting dalam penerapannya, guna untuk mengaitkan beberapa mata pelajaran didalamnya. hal-hal yang menyebabkan seorang guru harus membuat kaitan terhadap pembahasan yang di pelajari yaitu agar materi ajar lebih menarik, maka guru harus membuat kaitan materinya dengan pengetahuan yang mereka miliki, berdasarkan pengalaman yang dihadapi atau sesuai dengan minatnya. Kemudian mengingat materi pembelajaran yang telah diajarkan pada pertemauan sebelumnya, dengan menghubungkan dengan materi yang akan diajarkan sesudahnya, dengan materi pada pertemuan sebelumnya, maka siswa akan mengalami proses dimana ia akan mengingat kembali atau mengulang kembali materi yang dipelajari (membuka materi yang lalu sebagai dasar atau acuan materi.

Kemudian kegiatan terakhir dalam kegiatan pendahuluan adalah melakukan pre-tes atau tes awal. Dalam kegiatan pre test awal ini sangat penting dilakukan karena mengetahui pengetahuan awal siswa itu merupakan langkah awal yang harus dilakukan. Karena mengukur kemampuan siswa membuat guru menjadi tau apa yang harus dilakukan setelahnya mengenai pembelajaran yang akan diterapkan. Memberi beberapa pertanyaan diawal pembelajaran menjadikan siswa untuk berfikir dan menemukan sendiri konsep apa yang akan dipelajarinya. Dengan hal ini dapat menciptakan sebuah stimulus yang lalu akan direspon oelh siswa dalam 
proses penerapannya.semua yang dilakukan kedua lembaga ini dengan cara yang berbeda akan tetapi memiliki tujuan yang sama dalam menjalankan strategi pembelajaran yang diterapkan.

Strategi yang dilakukan pada model ini terletak pada pemilihan sebuah tema yang sesuai dengan minat dan kebutuhan peserta didik. Tema menjadi pemersatu setiap mata pelajaran yang akan diajarkan, jadi sangatlah penting pengorganisasian tema yang dipersiapkan sebelum proses pembelajaran. Setelah pemilihan tema yang sesuai dengan kebutuhan peserta didik penggunaan media pembelajaran juga sangat berpengaruh dalam proses pembelajaran tematik integratif karena guru yang kreatif menjadi modal utama dalam mensukseskan proses pembelajaran.. model ini akan menjadikan siswa lebih bisa memahami materi pembelajaran yang mendalam. Siswa akan bersemangan dan aktif dikelas. Keaktifan siswa menjadikan mereka lebih mandiri dan lebih bisa memberikan sebuah respon terhadap pembelajaran yang telah diterapkan. Pembelajaran tematik menekankan belajar sambil melakukan sesuatu (Hartono, 2013:156). Pengalaman guru menjadi penting untuk memadukan antara teori dan praktis serta menciptakan kesan belajar yang baik. Pengalaman belajar guru kemudian lebih memberikan kesan belajar yang sesungguhnya pada siswa. Konsep pembelajaran tematik secara tidak langsung akan membentuk skema konseptual dari materi pembelajaran sehingga ada proses kesinambungan dan pertautan antara materi yang dulu dengan sekarang. Pada saat itulah siswa akan mengetahui mata rantai pengetahuan konseptual.

\section{Media Pembelajaran yang Digunakan Guru Dalam Pembelajaran Tematik Integratif Berbasis Kurikulum 2013}

Media pembelajaran yang digunakan oleh kedua lembaga ini bervariasi dan selalu disesuaikan oleh kebutuhan peserta didik. Adapun media yang digunakan oleh guru MIN Yogyakarta II sangatlah beragam berupa media audio visual, media visual, media cetak. Dalam pembelajaran yang memerlukan media lingkungan dalam belajar guru selalu memberikan sebuah alternatif lain berupa video-video yang menarik tentang lingkungan. Media pembelajaran yang digunakan oleh guru MI Ma'had Islamy Kotagede Yogyakarta hampir sama dengan media yang digunakan oleh guru MIN Yogyakarta II, akan tetapi guru MI Ma'had Islamy lebih sering menggunakan media yang berbasis lingkungan sekitar sekolah. Kegiatan ini dilakukan oleh guru sebagai media yang digunakan agar kegiatan belajar lebih bervariasi. Kegiatan seperti ini dilakukan oleh guru agar memberikan variasi dalam kegiatan belajar dikelas Kesuksesan tujuan proses belajar berada digenggaman guru, maka semakin bermakna pembelajaran yang diberikan semakin besar juga kemungkinan pembelajaran tersebut dapat dipahami oleh siswa. Karena kehadiran media dalam proses pembelajaran dapat membantu guru dalam memberikan konsep pemahaman kepada siswa dalam proses pembelajaran. Penjabaran diatas dapat di ambil kesimpulan bahwa media sangat penting digunakan karena 
dapat memudahkan proses penyampaian materi pembelajaran dan juga membuat pembelajaran menjadi lebih berkesan dan bervariasi.

Keaktifan siswa dalam belajar tergantung dengan media apa yang diterapkan. Media menjadi suatu sarana yang digunakan untuk memudahkan guru dalam menjelaskan materi pembelajaran. Dengan kehadiran media membuat penjelasan yang semulanya sulit untuk dipahami menjadi mudah dan praktis untuk diterapkan. Strategi pembelajaran harus dipikirkan terlebih dahulu sbelum penerapannya. Media merupakan bagian yang sangat penting untuk dipertimbangkan karena pembelajaran akan lebih menarik dengan hadirnya media yang dapat mendukung proses pembelajaran menjadi simple dan menarik untuk disajikan. Media merupakan komponen penting yang berguna untuk merangsang kognitif siswa yang menimbulkan rasa ingin tau yang lebih tinggi seperti yang dijelaskan oleh Dengeng (1993: 215) dalam bukunya Trianto, bahwa media merupakan komponen penting yang berguna untuk merangsang kognitif siswa yang menimbulkan rasa ingin tau yang lebih tinggi.

\section{KESIMPULAN}

Penerapan model pembelajaran tematik integratif berbasis kurikulum 2013 di madrasah ibtidaiyah ini hendaknya dipersiapkan secara matang dan terstruktur. Seluruh komponen pembelajaran harus dirancang sedemikian rupa agar menarik dan memberikan pembelajaran yang bermakna bagi siswa. Pemahaman terhadap model pembelajaran, strategi dalam penerapan pembelajaran dan media yang akan digunakan merupakan poin penting yang harus dipersiapkan guru dalam menerapkan model pembelajaran tematik integratif berbasis kurikulum 2013. Inti dari penerapan pembelajaran tematik integrative ini menegaskan bahwa menjadi seorang pendidik haruslah kreatif dan bisa memahami semua jenis model pembelajaran yang akan diterapakan.

Terutama pada pembelajaran tematik integrative berbasis kurikulum 2013 di madrasah ibtidaiyah ini. Guru dituntut untuk bisa menggabungkan beberapa mata pelajaran kedalam sebuah tema yang telah disusun sehingga menjadi pembelajaran yang bermakna bagi peserta didik. Kesusksesan dalam penerapan model pembelajaran ini tergantung dengan kreatifitas guru dalam menentukan strategi pembelajaran, media yang digunakan dalam proses pembelajaran dan apapun yang dianggap penting untuk kelangsungan belajar mengajar. agar tujuan membelajaran dapat tercapai. 
Jefryadi

\section{DAFTAR PUSTAKA}

Abdul Haling. (2006). Belajar dan Pembelajaran. Makassar: Badan Penerbit Universitas Negeri Makassar.

Arikunto, Suharsimi. (1993). Prosedur Penelitian Suatu Pendekatan Praktek. Jakarta: Rineka Cipta.

Depdikbud. (2002). Model-Model Pembelajaran Dirjen Pendidikan Dasar dan Menengah Departemen Pendidikan Nasional. Jakarta. PGSM.

Depdiknas. (2001). Buku 1 Manajemen Peningkatan Mutu Pendidikan Berbasis Sekolah. Jakarta: Depdikbud.

Dimyati \& Mudjiono. (2006). Belajar dan Pembelajaran. Jakarta: Rineka Cipta.

Hajar, Ibnu. (2013). Panduan Lengkap Kurikulum Tematik SD/MI. Jogjakarta: DIVA Press.

Hartono, Rudi (2013). Ragam Model Mengajar yang Mudah Diterima Murid. Yogyakarta: Diva Press.

Hidayat, Sholeh. (2013). Pengembangan Kurikulum Baru. Bandung: PT Remaja Rosdakarya. http:/ / www.ditnaga-dikti.org/ditnaga/files/PIP/tematik.pdf

Isna Aunillah, Nurla. (2011). Panduan Menerapkan Pendidikan Kerakter di Sekolah. Jogjakarta : Laksana.

J. Mursell, S. Nasution, (2006). Mengajar dengan Sukses. Jakarta : Bumi Aksara.

Nasution, S. (2008). Berbagai Pendekatan dalam Proses Belajar Mengajar. Bandung: Bumi Aksara

Prastowo, Andi. (2014). Pengembangan Bahan Ajar Tematik Tinjauan Teoritis dan Praktis. Jakarta: Kencana.

Prihatin, Eka. (2011). Manajemen peserta Didik. Bandung: Alfabeta

Sanjaya, Wina. (2006). Strategi Pembelajaran. Bandung : Kencana Prenadamedia Grup,

Slameto. (2003). Belajar dan Faktor-Faktor yang Mempengarubinya. Jakarta: Rineka Cipta.

Soleh, Moh. (2014). Metotologi Pembelajaran Kontemporer. Yogyakarta: KAUKABA.

Sudjana, Nana. (1996). Cara Belajar Siswa Aktif dalam Proses Belajar mengajar. Bandung: Sinar Baru Algesindo.

Sugiyono. (2006). Metode Penelitian Pendidikan. Bandung: Alfabeta.

Suryosubroto. 1997. Proses Belajar-Mengajar di Sekolah. Jakarta: Rineka Cipta.

Syah, Muhibbin. (2004). Psikologi Pendidikan Dengan Pendekatan Baru. Bandung: Remaja Rosda Karya.

Trianto. (2010). Model Pembelajaran Terpadu. Jakarta : Bumi Aksara. 
Triyanto. (2009). Pengembangan Model Pembelajaran Tematik. Jakarta: PT.Prestasi Pustakaraya, Usman, Moh Uzer. 2000. Menjadi Guru Profesional. Bandung: Remaja Rosdakarya

Yusak, Muchlas. (2003). Wawasan Kependidikan, Empat Pilar Pendidikan. Semarang: Lembaga Penjamin Mutu Pendidikan 